\title{
The effect of percutaneous mitral balloon valvuloplasty on left atrial systolic functions
}

\author{
Wpływ przezskórnej komisurotomii mitralnej na czynność skurczową lewego przedsionka \\ Hekim Karapinar ${ }^{1,2}$, Mehmet Y. Emiroglu², Soe M. Aung², Zekeriya Kaya², Yusuf Karavelioglu², \\ Zekeriya Kucukdurmaz', Ibrahim Gul', Ali M. Esen², Cevat Kirma² \\ 1Department of Cardiology, Cumhuriyet University Faculty of Medicine, Sivas, Turkey \\ 2Department of Cardiology, Kartal Kosuyolu Cardiovascular Research and Training Hospital, Istanbul, Turkey
}

Post Kardiol Interw 2011; 7, 3 (25): 201-205

DOI: $10.5114 /$ pwki.2011.24736

\begin{abstract}
Background: Conventional echocardiographic methods have already shown that successful mitral balloon valvuloplasty (MBV) can effectively increase left atrial (LA) functions.

Aim: To evaluate LA functions after MBV using colour tissue Doppler imaging.

Material and methods: Sixty-eight patients (58 females, mean age: $38 \pm 12$ years) were included in the study. Within $24 \mathrm{~h}$ before $M B V$, all the patients underwent colour tissue Doppler study in addition to routine conventional echocardiographic examinations. Late diastolic velocities (A') measured at the LA wall adjacent to the septal and lateral annuli were recorded. All the measurements were repeated $24 \mathrm{~h}$ after MBV. The MBV was done using the Inoue technique. Successful MBV patients were included in group A and those who developed severe mitral regurgitation (MR) were included in group $B$.

Results: Sixty-one patients underwent successful MBV while 7 developed MR. Mitral valve areas (MVA) in both groups were significantly increased. Maximum and mean gradients, LA diameter, systolic pulmonary arterial pressure and mean LA pressures were decreased while septal and lateral A' were significantly increased in group A. In group B, no significant change in any variable was found except for the increase in MVA.

Conclusions: After successful MBV, increase in A' velocity was seen in parallel to the recovery of LA functions. Early improvements in left atrial systolic functions after successful MBV can easily be determined by colour tissue Doppler as a quick and reliable method.
\end{abstract}

Key words: mitral stenosis, valvuloplasty, left atrial functions, tissue Doppler echocardiography

\section{Streszczenie}

Wstęp: W standardowych badaniach echokardiograficznych wykazano, że po skutecznym zabiegu przezskórnej komisurotomii mitralnej (PKM) dochodzi do istotnej poprawy funkcji lewego przedsionka.

Cel: Ocena funkcji lewego przedsionka po PKM przy użyciu badania kolorowego dopplera tkankowego.

Materiał i metody: Do badania włączono 68 pacjentów (58 kobiet, średni wiek $38 \pm 12$ lat). U wszystkich pacjentów, oprócz standardowego badania echokardiograficznego, wykonano badanie metodą dopplera tkankowego w ciągu 24 godzin przed zabiegiem PKM. Rejestrowano prędkość późnorozkurczową (A') mierzoną w ścianie lewego przedsionka przylegającej do przegrodowej i bocznej części pierścienia. Wszystkie pomiary powtórzono po 24 godzinach od PKM. Badanie to wykonano według techniki Inoue. Pacjentów, u których wykonano skuteczny zabieg PKM, włączono do grupy A. Osoby, u których po zabiegu wystąpiła ciężka niedomykalność zastawki mitralnej (ang. mitral regurgitation, MR), włączono do grupy B.

Wyniki: Skuteczne badanie PKM wykonano u 61 pacjentów, a u 7 osób wystąpiła MR. Pole powierzchni zastawki mitralnej (ang. mitral valve area, MVA) wzrosło istotnie w obu grupach. W grupie A zaobserwowano redukcję maksymalnego i średniego gradientu, wymiaru lewego przedsionka, skurczowego ciśnienia w tętnicy płucnej i średniego ciśnienia w lewym przedsionku oraz wzrost prędkości przegrodowej i bocznej (A'). W grupie B nie zaobserwowano istotnej zmiany w żadnym z analizowanych parametrów, z wyjątkiem wzrostu MVA.

Wnioski: Po skutecznym zabiegu PKM obserwowano wzrost prędkości A' oraz poprawę funkcji lewego przedsionka. Wczesna poprawa funkcji skurczowej lewego przedsionka po skutecznym zabiegu PKM może być łatwo oceniona w badaniu kolorowego dopplera tkankowego, które jest szybką i wiarygodną metodą.

Słowa kluczowe: zwężenie zastawki mitralnej, walwuloplastyka, funkcja lewego przedsionka, echokardiografia metodą dopplera tkankowego

Corresponding author/Adres do korespondencji:

Hekim Karapinar MD, Assist. Prof. Cumhuriyet Universitesi, Araștırma ve Uygulama Hastanesi Kardiyoloji Anabilim Dalı, 58140 Sivas, Turkey, tel.: +90 505 3149560, fax: +90 346 2191155, e-mail: drhekim@yahoo.com

Praca wptynęła: 12.08.2011, przyjęta do druku: 31.08.2011. 


\section{Introduction}

Left atrial (LA) functions play an important role in patients with mitral stenosis. The contribution of the LA kick to cardiac output is $24 \%$ in mild mitral stenosis, decreasing to $15 \%$ in severe mitral stenosis [1-4]. Percutaneous mitral balloon valvuloplasty (MBV) is an effective therapeutic choice for suitable cases [5]. The MBV is ever effective in unsuitable situations for surgery [6]. The LA dysfunctions in mitral stenosis (MS) and subsequent recovery following successful MBV have been documented by conventional echocardiographic methods [4, 7]. However, there is currently no widely accepted non-invasive 'gold standard' method to evaluate atrial functions. In comparison to ventricular function, there is a paucity of literature regarding the evaluation of atrial functions [8]. Evaluation of LA functions by the conventional echocardiographic method is not only time-consuming but also has a low reproducibility $[9,10]$. Mitral inflow late diastolic wave (A wave) determined by pulsed wave Doppler has been used to evaluate LA function. However, peak $A$ wave velocity is influenced by heart rate, loading conditions and aging [11]. A relatively new method, tissue Doppler imaging (TDI), is less influenced by volume status, easy to apply and possesses a high reproducibility [12-15]. It has been reported that late diastolic wave is well correlated with LA systolic functions [16, 17].

\section{Aim}

We aimed to study the LA systolic functions early after MBV when there is a dramatic and substantial decrease in afterload with the use of TDI.

\section{Material and methods}

Sixty-eight consecutive patients ( 58 females, mean age: $38 \pm 12$ years) who underwent MBV between January 2007 and June 2008 were included in the study. Patient selection for MBV was done according to the ACC/AHA guidelines [18]; symptomatic patients [New York Heart Association (NYHA) functional class $\geq I 1$ ] with MVA $\leq 1.0 \mathrm{~cm}^{2}$ or $1.0^{-} 1.5 \mathrm{~cm}^{2}$, MVA $\leq 1.0 \mathrm{~cm}^{2}$ or $1.0-1.5 \mathrm{~cm}^{2}$ with systolic pulmonary artery pressure greater than $50 \mathrm{mmHg}$ at rest or greater than 60 $\mathrm{mmHg}$ with exercise, patients with appropriate mitral valve morphology for MBV, patients with no moderate to severe MR or left atrial thrombus or concomitant severe valvular disease. Moreover, patients with rhythm disorder, coronary artery disease, diabetes, hypertension and chronic obstructive or restrictive lungs disease were excluded from the study. Successful MBV patients without severe MR were included in group $A$, whereas those who developed severe MR after MBV were taken as group B. Written informed consent was taken from all patients, and the study was approved by the local ethics committee.

\section{Procedure and echocardiographic examination}

Detailed transthoracic echocardiographic examination (TTE) was performed within $24 \mathrm{~h}$ before MBV. Conventional Doppler examination was done in accordance with previously determined criteria $[19,20]$. Using colour TDI, late diastolic wave velocities ( $A^{\prime}$ ) of the left atrium adjacent to the septal and lateral annulus were measured (fig. 1). As far as possible, Doppler was placed perpendicular to the mitral annular plane, the depth was decreased to a minimum, and a narrow sector width with a high frame rate was used. All the measurements were repeated $24 \mathrm{~h}$ after MBV. The TTE was done using GE VingMed system 5 (GE, Horten, Norway) with a 2.5-3.5 $\mathrm{mHz}$ probe. Analysis was done with EchoPac version 6.5. MBV was performed using the Inoue technique with the help of TTE [21]. Increase of MVA over $1.5 \mathrm{~cm}^{2}$ in the absence of severe MR or a drop of mean transmitral gradient below $10 \mathrm{mmHg}$ was regarded as a successful MBV.

\section{Statistical analysis}

Parametric variables are given as mean \pm standard deviation. Categorical variables are given as frequency and per-

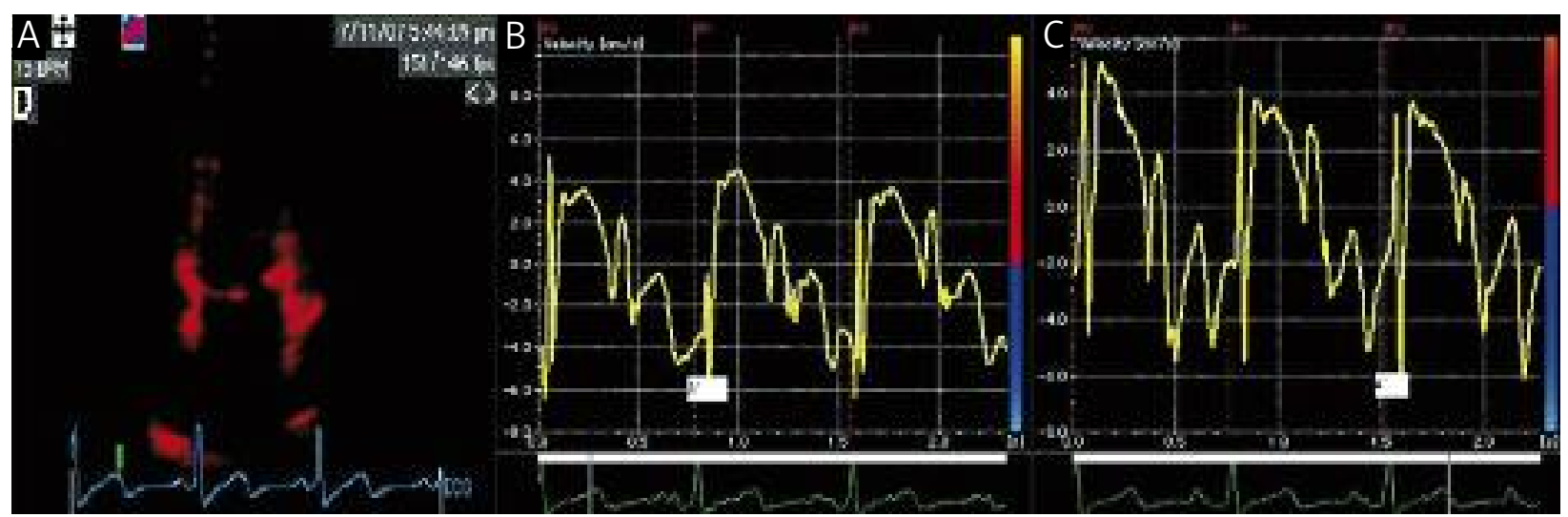

Fig. 1. Colour tissue Doppler image of left atrium in the apical 4-chamber view (A), TDI velocity of septal wall before (B) and after the procedure (C)

Ryc. 1. Badanie przy użyciu kolorowego dopplera tkankowego. Projekcja koniuszkowa 4-jamowa (A). Prędkość TDI ściany bocznej przed zabiegiem (B) i po zabiegu (C) 
Table 1. Comparison of baseline properties of the two groups

Tabela 1. Porównanie charakterystyki podstawowej obu grup

\begin{tabular}{|c|c|c|c|}
\hline Paramaters & Group A $(n=61)$ & Group B $(n=7)$ & Value of $p$ \\
\hline Age [years] & $38 \pm 9$ & $39 \pm 9$ & 0.81 \\
\hline Female gender $n(\%)$ & $52(85)$ & $6(86)$ & 0.85 \\
\hline Mitral valve area - planimetric [ $\left.\mathrm{cm}^{2}\right]$ & $1.19 \pm 0.26$ & $1.03 \pm 0.11$ & 0.14 \\
\hline Maximum gradient [mmHg] & $19.6 \pm 6.3$ & $20.7 \pm 6.9$ & 0.68 \\
\hline Mean gradient [mmHg] & $11.3 \pm 4.6$ & $12.2 \pm 4.4$ & 0.63 \\
\hline Systolic pulmonary arterial pressure [mmHg] & $48.1 \pm 12.0$ & $45.1 \pm 6.8$ & 0.59 \\
\hline Left atrial diameter [cm] & $4.2 \pm 0.6$ & $4.4 \pm 0.4$ & 0.55 \\
\hline Mean left atrial pressure [mmHg] & $25.4 \pm 3.3$ & $25.6 \pm 1.1$ & 0.45 \\
\hline Lateral annular A' wave velocity [cm/s] & $5.32 \pm 1.17$ & $5.34 \pm 1.57$ & 0.98 \\
\hline Septal annular A' wave velocity [cm/s] & $4.84 \pm 1.04$ & $4.56 \pm 0.59$ & 0.49 \\
\hline
\end{tabular}

Table 2. Comparison of pre- and post-procedural parameters

Tabela 2. Porównanie wskaźników przed zabiegiem i po zabiegu

\begin{tabular}{lcccccc} 
Parameters & \multicolumn{3}{c}{ Group A $(n=61)$} & \multicolumn{3}{c}{ Group B $(n=7)$} \\
\cline { 2 - 7 } & $\begin{array}{c}\text { Before } \\
\text { MBV }\end{array}$ & $\begin{array}{c}\text { After } \\
\text { MBV }\end{array}$ & Value of $p$ & $\begin{array}{c}\text { Before } \\
\text { MBV }\end{array}$ & $\begin{array}{c}\text { After } \\
\text { MBV }\end{array}$ & Value of $p$ \\
\hline Mitral valve area - planimetric $\left[\mathrm{cm}^{2}\right]$ & $1.19 \pm 0.26$ & $1.90 \pm 0.27$ & $<0.001$ & $1.03 \pm 0.11$ & $1.84 \pm 0.21$ & $<0.001$ \\
\hline Maximum gradient $[\mathrm{mmHg}]$ & $19.6 \pm 6.3$ & $9.8 \pm 2.8$ & $<0.001$ & $20.7 \pm 6.9$ & $18.4 \pm 11.3$ & 0.53 \\
\hline Mean gradient $[\mathrm{mmHg}]$ & $11.3 \pm 4.6$ & $4.9 \pm 1.8$ & $<0.001$ & $12.2 \pm 4.4$ & $8.6 \pm 5.1$ & 0.14 \\
\hline $\begin{array}{l}\text { Systolic pulmonary arterial } \\
\text { pressure }[\mathrm{mmHg}]\end{array}$ & $48.1 \pm 12.0$ & $34.6 \pm 9.5$ & $<0.001$ & $45.1 \pm 6.8$ & $42.7 \pm 11.2$ & 0.59 \\
\hline Left atrial diameter $[\mathrm{cm}]$ & $4.2 \pm 0.6$ & $3.9 \pm 0.6$ & $<0.001$ & $4.4 \pm 0.4$ & $4.2 \pm 0.4$ & 0.37 \\
\hline Mean left atrial pressure $[\mathrm{mmHg}]$ & $25.4 \pm 3.3$ & $14.8 \pm 3.1$ & $<0.001$ & $25.6 \pm 1.1$ & $26.1 \pm 1.4$ & 0.59 \\
\hline Lateral annular A' wave velocity $[\mathrm{cm} / \mathrm{s}]$ & $5.32 \pm 1.17$ & $6.04 \pm 1.23$ & $<0.001$ & $5.34 \pm 1.57$ & $5.50 \pm 1.04$ & 0.67 \\
\hline Septal annular A' wave velocity $[\mathrm{cm} / \mathrm{s}]$ & $4.84 \pm 1.04$ & $5.49 \pm 1.16$ & $<0.001$ & $4.56 \pm 0.59$ & $4.71 \pm 0.44$ & 0.21
\end{tabular}

centage. Variables before and after the procedure in group $A$ and $B$ were compared using paired sample t-test. Pearson correlation coefficient was used for parametric variables, and Spearman correlation analysis used for categorical variables. Statistical analysis was performed using SPSS (version 17.0, SPSS inc., Chicago, IL, USA). A $p$ value $<0.05$ was considered statistically significant.

\section{Results}

The MBV was successful in 61 patients while 7 patients developed severe MR. Both groups were similar for age and gender. Also, they have similar MVA, maximum and mean transmitral gradients, LA diameter and pressure, systolic pulmonary arterial pressure (PAP), left ventricular (LV) functions and septal and lateral A' velocities (tab. 1). The MVA of both groups increased significantly after the procedure. Maximum and mean gradients, LA diameter, systolic PAP and mean LA pressure decreased significantly, and septal and lateral $A^{\prime}$ increased significantly in group A. As for group B, no significant change was observed apart from MVA (tab. 2). In correlation analysis, neither septal nor lateral A' was found to be correlated with age or gen$\operatorname{der}(p>0.05)$. Among pre-procedural parameters, septal and lateral A' showed mild to moderate correlation with MVA $(r=0.327, p=0.017 ; r=0.311, p=0.022$, respectively), and moderate inverse correlation with LA pressure ( $r=-0.662, p<0.001 ; r=-0.599, p<0.001$, respectively) (fig. 2). Among post-procedural parameters, septal and lateral A' velocities were found to be moderately inversely correlated only with LA pressure $(r=-0.448, p<0.001$; $r=-0.476, p<0.001$, respectively).

\section{Discussion}

In our study, it was found that A' velocity, which is an indicator of LA systolic functions, increased with successful MBV. But no such increase was seen in patients who developed severe MR after the procedure.

It is known that systolic dysfunctions of the LA and LA appendage occur to a varying degree in patients with mitral stenosis, thereby forming spontaneous echo contrast and 

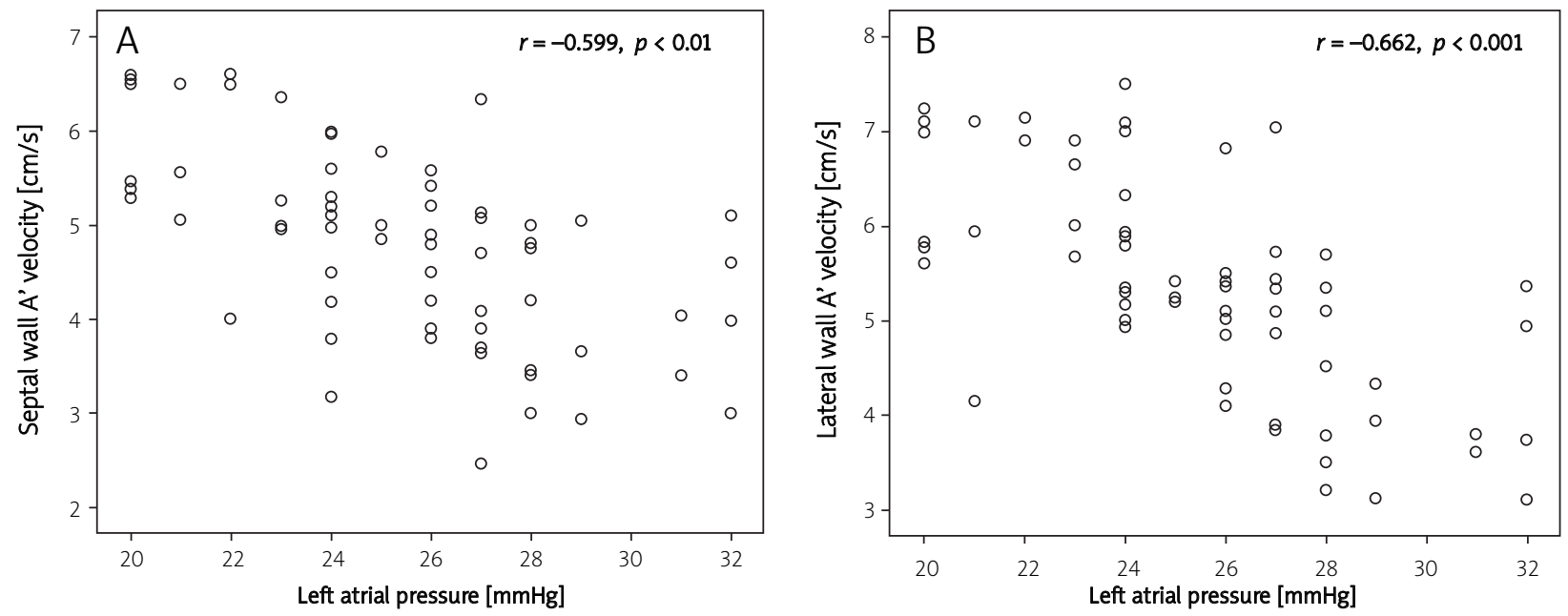

Fig. 2. Correlation between septal wall $A^{\prime}$ velocity and left atrial pressure $(A)$ and correlation between lateral wall $A^{\prime}$ velocity and left atrial pressure (B)

Ryc. 2. Korelacja pomiędzy prędkością A' ściany bocznej i ciśnieniem w lewym przedsionku (A) oraz pomiędzy prędkością A' ściany bocznej i ciśnieniem w lewym przedsionku (B)

thrombus. This dysfunction has been shown by conventional [7] and TDI methods [15]. The same methods have also been used to show the improvement of LA functions after MBV [4, 7]. Conventionally, quantitative assessment of LA functions is made by measurements of area and volume at respective phases of the cardiac cycle. As a number of measurements and calculations are needed, reproducibility and clinical application are limited [22]. The efficacy of TDI has been shown, and its use is becoming more and more widespread. Being less affected by volume status, TDI has been shown to be more accurate in evaluation of myocardial systolic and diastolic functions, especially in patients undergoing valvuloplasty or haemodialysis and those with decompensated heart failure where rapid changes in preload and afterload are common [2325]. It has been shown previously that late diastolic motion of the mitral annulus reflected LA and LA appendage functions [16]. In our study, it was found that septal and lateral A' velocity was increased in patients who had successful MBV, whereas no such increase was seen in patients who developed severe MR.

Bauer et al. showed that E' and A' velocity measured by TDI at the LA appendage was increased significantly at day one after MBV [26]. Karakaya et al. [27] found that systolic motion of the LA appendage at the late diastolic phase was significantly increased at the third day after MBV. Cianciulli et al. [28] performed transoesophageal echocardiography (TEE) at the sixth month after MBV to evaluate LA appendage functions by TDI, and improvement was seen. Our study showed that the evaluation could also be done by TTE instead of TEE. The results were supported by the absence of improvement in LA functions in patients who developed severe MR. In a study done with healthy subjects, $A^{\prime}$ was found to increase with age [12]. However, such a finding was not seen in our study. This could probably be related to different degrees of valvular involvement.

Lateral and septal A' velocities were mild to moderately correlate with MVA, while no correlation was present with transmitral maximum and mean gradient and systolic PAP. As known, A' velocity was determined by afterload and intrinsic contractility of LA [28]. Afterload of LA is equivalent to the LA pressure before atrial systole. In patients with mitral stenosis, the presence and severity of MR and left ventricular end-diastolic pressure determine LA afterload in addition to MVA. Thus, a limited correlation between A' velocity and MVA and the lack of correlation with transmitral gradients are not unexpected. In our study, LA pressure measured invasively was found to be inversely related to A' velocity. This shows that even if MVA increases after MBV, the development of severe MR could prevent the fall in LA pressure and a notable increase in $A^{\prime}$ velocity.

Although an increase in A' velocity after MBV was shown, further studies are needed to find out its relationship with the decrease in the incidence of atrial fibrillation and thromboembolism and the effect on morbidity and mortality in the long run.

\section{Limitations}

In our study, measurement of A' velocity was not confirmed with other imaging modalities such as magnetic resonance imaging. However, the efficacy of TDI has been proved in different populations and different studies [26-29]. Moreover, LA segmental systolic functions were not studied. Nevertheless, annular velocity has been shown to be indicative of LA functions [12]. In our study, LA velocities were taken from an area adjacent to the annuli. 


\section{Conclusions}

Left atrial septal and lateral A' velocities were shown to be increased after successful MBV. No increase of $A^{\prime}$ velocity was seen in those who developed severe MR. Tissue velocity measured in TTE could effectively show early changes in LA function after successful MBV.

\section{Acknowledgements}

The authors have no conflict of interest or financial support for this work.

\section{References}

1. Barbier P, Solomon SB, Schiller NB, Glantz SA. Left atrial relaxation and left ventricular systolic function determine left atrial reservoir function. Circulation 1999; 100: 427-436.

2. Stojnic B, Krajcer Z, Anicic S, et al. Use of continuous wave Doppler echocardiography to evaluate the hemodynamic importance of atrial systole in patients with mitral stenosis. J Am Soc Echocardiogr 1989; 2: 172-176.

3. Stefanadis C, Dernellis J, Lambrou S, et al. Left atrial energy in normal subjects, in patients with symptomatic mitral stenosis, and in patients with advanced heart failure. Am J Cardiol 1998; 82: 1220-1223.

4. Stefanadis C, Dernellis J, Stratos C, et al. Effects of balloon mitral valvuloplasty on left atrial function in mitral stenosis as assessed by pressure area relation. J Am Coll Cardiol 1998; 32: 159-168.

5. Chmielak Z, Karcz M, Kruk M, et al. Twenty years' experience with percutaneous mitral commissurotomy. Post Kardiol Interw 2008; 4: 89-96.

6. Dąbrowski M, Chmielak Z, Dąbrowski M, et al. Percutaneous mitral commissurotomy in pregnant women - long-term observations. Post Kardiol Interw 2011; 7: 15-19.

7. Bitigen A, Türkmen M, Karakaya O, et al. Early effects of percutaneous mitral valvuloplasty on left atrial mechanical functions. Tohoku J Exp Med 2006; 209: 285-289.

8. Thomas L. Assessment of atrial function. Heart Lung Circ 2007; 16: 234-242.

9. Wade MR, Chandraratna PA, Reid CL, et al. Accuracy of nondirected and directed $\mathrm{M}$-mode echocar diography as an estimate of left atrial size. Am J Cardiol 1987; 60: 1208-1211.

10. Wang Y, Gutman JM, Heilbron D, et al. Atrial volume in a normal adult population by two dimensional echocardiography. Chest 1984; 86: 595-601.

11. Choong CY, Herrmann HC, Weyman AE, et al. Preload dependence of Doppler-derived indexes of left ventricular diastolic function in humans. J Am Coll Cardiol 1987; 10: 800-808.

12. Thomas L, Levett K, Boyd A, et al. Changes in regional left atrial function with aging: evaluation by Doppler tissue imaging. Eur J Echocardiogr 2003; 4: 92-100.

13. Thomas L, Boyd A, Thomas SP, et al. Atrial structural remodelling and restoration of atrial contraction after linear ablation for atrial fibrillation. Eur Heart J 2003; 24: 1942-1951.

14. Alam M, Wardell J, Andersson E, et al. Characteristics of mitral and tricuspid annular velocities determined by pulsed wave Doppler tissue imaging in healthy subjects. J Am Soc Echocardiogr 1999; 12: 618-628.
15. Ozdemir K, Altunkeser BB, Gok H, et al. Analysis of the myocardial velocities in patients with mitral stenosis. J Am Soc Echocardiogr 2002; 15: 1472-1478.

16. Khankirawatana B, Khankirawatana S, Peterson B, et al. Peak atrial systolic mitral annular velocity by Doppler tissue reliably predicts left atrial systolic function. J Am Soc Echocardiogr 2004; 17: 353-360.

17. Hesse B, Schuele SU, Thamilasaran M, et al. A rapid method to quantify left atrial contractile function: Doppler tissue imaging of the mitral annulus during atrial systole. Eur J Echocardiogr 2004; 5: 86-92.

18. Bonow RO, Carabello BA, Kanu C, et al. ACC/AHA 2006 guidelines for the management of patients with valvular heart disease: a report of the American College of Cardiology/American Heart Association Task Force on Practice Guidelines (writing committee to revise the 1998 Guidelines for the Management of Patients With Valvular Heart Disease): developed in collaboration with the Society of Cardiovascular Anesthesiologists: endorsed by the Society for Cardiovascular Angiography and Interventions and the Society of Thoracic Surgeons. Circulation 2006; 114: e84-e231.

19. Gottdiener JS, Bednarz J, Devereux R, et al. American Society of Echocardiography recommendations for use of echocardiography in clinical trials. J Am Soc Echocardiogr 2004; 17: 1086-1119.

20. Quinones MA, Otto CM, Stoddard M, et al. Recommendations for quantification of Doppler echocardiography: a report from the Doppler Quantification Task Force of the Nomenclature and Standards Committee of the American Society of Echocardiography. J Am Soc Echocardiogr 2002; 15: 167-184.

21. Inoue K. Percutaneous transvenous mitral commissurotomy using the Inoue balloon. Eur Heart J 1991; 12 (Suppl B): 99-108.

22. Jenkins C, Bricknell K, Marwick TH. Use of real-time three-dimensional echocardiography to measure left atrial volume: comparison with other echocardiographic techniques. J Am Soc Echocardiogr 2005; 18: 991-997.

23. Diwan A, McCulloch M, Lawrie GM, et al. Doppler estimation of left ventricular filling pressures in patients with mitral valve disease. Circulation 2005; 111: 3281-3289.

24. Garcia MJ, Rodriguez L, Ares M, et al. Differentiation of constrictive pericarditis from restrictive cardiomyopathy: assessment of left ventricular diastolic velocities in longitudinal axis by Doppler tissue imaging. J Am Coll Cardiol 1996; 27: 108-114.

25. Hasegawa H, Little W, Ohno M, et al. Diastolic mitral annular velocity during the development of heart failure. J Am Coll Cardiol 2003; 41: 1590-1597.

26. Bauer F, Verdonck A, Schuster I, et al. Left atrial appendage function analyzed by tissue Doppler imaging in mitral stenosis: effect of afterload reduction after mitral valve commissurotomy. J Am Soc Echocardiogr 2005; 18: 934-939.

27. Karakaya O, Turkmen M, Bitigen A, et al. Effect of percutaneous mitral balloon valvuloplasty on left atrial appendage function: a Doppler tissue study. J Am Soc Echocardiogr 2006; 19: 434-437.

28. Cianciulli TF, Saccheri MC, Lax JA, et al. Left and right atrial function after percutaneous mitral valvuloplasty in mitral stenosis and sinus rhythm. J Heart Valve Dis 2008; 17: 492-500.

29. Nagueh SF, Sun H, Kopelen HA, et al. Hemodynamic determinants of the mitral annulus diastolic velocities by tissue Doppler. J Am Coll Cardiol 2001; 37: 278-285. 